\title{
Diagnostic tools and therapeutic end-points in critical care medicine: Limitations and concepts
}

\author{
Sandy S P Severino', Susan Marum², Paulo A R Marcelino ${ }^{3}$ \\ 1. CHLC: Hospital Curry Cabral - ICU, Portugal. 2. IPO Lisboa, Portugal. 3. CEDOC - Faculdade de Ciências Médicas da \\ Universidade Nova de Lisboa, Portugal. \\ Correspondence: Sandy S P Severino. Address: CHLC: Hospital Curry Cabral - ICU, Portugal. \\ Email: sandyseverino@gmail.com
}

Received: May 31, 2013

Accepted: October 20, 2013

Online Published: May 9, 2014

DOI : 10.5430/jnep.v4n7p129

URL: http://dx.doi.org/10.5430/jnep.v4n7p129

\begin{abstract}
In Intensive Care Medicine (ICM) the presence of multiple high tech devices is common in order to perform multiple medical and non-medical procedures. The authors intend to perform a critical appraisal on the basic and practical/clinical approach to monitoring devices, analyzing the evidence support regarding clinical effects, end-points, and patient safety. All data that provides a diagnosis or a characterization of the patient's status will be considered diagnostic information whereas, variables that could be achieved by medical interventions will be considered therapeutic end-points. In any healthcare setting a careful approach to the patient is needed, namely in ICM one must consider the patient's clinical condition and choose adequate diagnostic tools and devices. Not all variables and devices currently on the market are suitable for each patient, nor proved useful in the setting under study. Also, all patients are different and must be approached differently according to established clinical end-points, translating into more holistic caregiving. ICM requires a personalized approach towards the patient, consequently, submitting diagnostic tools and monitoring devices to greater scrutiny in order to obtain greater patient benefit.
\end{abstract}

\section{Key words}

Hemodynamics, Diagnostic tools, Bioethics

\section{I ntroduction}

In Intensive Care Medicine (ICM) the presence of multiple devices is common. They are generally high tech places, where multiple medical and non-medical procedures take place. In this review, we intend to call attention to the excessive monitoring of the critically ill, analyzing the evidence that supports this monitoring practice, as well as, analyzing the meaning of the involved concepts. The way each technical device, and in particular monitoring devices, influence the patient's outcome is still yet to be determined. Nonetheless, the introduction of a specific device in an ICM ward is not dependent on the pre-existing evidence of any particular advantage, rather on a new method or concept that swiftly enters the medical practice. As an example we can mention the Pulse Indicator Continuous Cardiac Output (PiCCO) monitoring system. The approval took basically into consideration technical data and did not include any patient trials regarding end-points such as reduction in mortality or other outcome data ${ }^{[1]}$. In fact, the first trial addressing this issue is now ongoing and is currently in the phase of patient selection. This trial clearly addresses the possibility of a null effect on patient outcome, taking the Pulmonary Artery Catheter (PAC) as reference ${ }^{[2]}$. The authors intend to review the basic and 
practical approach to monitoring devices in ICM, their use, how they are related, and their conformity to recognized therapeutic end-points. As diagnostic information, we will consider all data that provides a diagnosis or a characterization of the patient's status; as therapeutic end-points we will consider variables that should/could be achieved (modified) by medical interventions. This issue will also be briefly approached from a bioethical standpoint.

\section{Monitoring devices}

The most significant example among the popularized monitoring devices in ICM is the PAC ${ }^{[3-6]}$. After the description by Swan et al. ${ }^{[7]}$, who described the possibility of its use at bedside, it was introduced in 1976 as a non-life saving device, and no previous testing regarding outcome modification and patient safety was required prior to its implementation. After 20 years of practice, the conclusion that its use can lead to an increased mortality was reached, regardless of disease severity ${ }^{[8]}$. No explanation for this fact is known or accepted. The invasiveness cannot be taken into account, thus the morbidity related to the insertion itself seems to be irrelevant. But a closer look at the practice around the PAC can provide some explanations. PACs permit constant monitoring of physiological variables. The concepts were built by the analysis of the different patient hemodynamic profiles, namely patients with sepsis ${ }^{[9-12]}$. It was observed that survivors of sepsis are able to achieve the so-called hyperdynamic profile, resulting in a higher cardiac output (CO). Also, by analysis of the oxygen extraction $\left(\mathrm{EO}_{2}\right)$ and the resulting mixed venous oxygen saturation $\left(\mathrm{SvO}_{2}\right)$, it was noticed that the peripheral tissues are unable to consume oxygen. So the rationale of providing a higher oxygen delivery $\left(\mathrm{DO}_{2}\right)$ was generally accepted. The variables dependent on $\mathrm{DO}_{2}$ are the $\mathrm{CO}$, the oxygen content (note that only oxygen carried by hemoglobin is used for tissue respiration), the arterial oxygen saturation $\left(\mathrm{SO}_{2}\right)$, and, in a small proportion, the arterial oxygen partial pressure $\left(\mathrm{PaO}_{2}\right)$. The normal values for the dependent variables are depicted in Table 1, and the formulas for the calculation of several hemodynamic parameters are depicted in Table 2.

Table 1. Reference values for the main hemodynamic parameters

\begin{tabular}{lll}
\hline Parameters & Limits & Units \\
\hline CVP & $1-6$ & $\mathrm{mmHg}$ \\
PW & $6-12$ & $\mathrm{mmHg}$ \\
$\mathrm{CI}$ & $2.4-4.0$ & $\mathrm{l} / \mathrm{min} / \mathrm{m}^{2}$ \\
LVWI & $40-60$ & $\mathrm{~g} \cdot \mathrm{m} / \mathrm{m}^{2}$ \\
RVWI & $4-8$ & $\mathrm{~g} \cdot \mathrm{m} / \mathrm{m}^{2}$ \\
SVR & $1600-2400$ & dyn.sec.m $/ \mathrm{cm}^{5}$ \\
PVR & $200-400$ & dyn.sec.m $/ \mathrm{cm}^{5}$ \\
$\mathrm{SVO}_{2}$ & $70-75$ & $\%$ \\
$\mathrm{DO}_{2}$ & $520-570$ & $\mathrm{ml} / \mathrm{min} / \mathrm{m}^{2}$ \\
$\mathrm{VO}_{2}$ & $110-160$ & $\mathrm{ml} / \mathrm{min} / \mathrm{m}^{2}$ \\
$\mathrm{EO}_{2}$ & $20-30$ & $\%$ \\
\hline
\end{tabular}

Legend: CVP, central venous pressure; Pw, pulmonary arterial wedge pressure; CI, cardiac index; LVWI, left ventricular work index; RVWI, right ventricular work index; SVR, systemic vascular resistance; PVR, pulmonary vascular resistance; $\mathrm{SVO}_{2}$, mixed venous oxygen saturation; $\mathrm{DO}_{2}$, oxygen delivery; $\mathrm{VO}_{2}$, oxygen consumption; $\mathrm{EO}_{2}$, oxygen extraction

Source: Marino, Paul. The ICU Book 2nd Edition. 1998, William and Wilkins, Baltimore USA, page 160

Table 2. Determination of some hemodynamic variables

\begin{tabular}{ll}
\hline Parameter & Calculation formula \\
\hline Body Surface Index (DuBois formula), $\mathrm{m}^{2}$ & {$[\mathrm{Ht}(\mathrm{cm})+\mathrm{Wt}(\mathrm{kg})-60]-100$} \\
Cardiac Index (CI) & $\mathrm{CO} / \mathrm{BSI}$ \\
$\mathrm{SVRI}$ & $(\mathrm{MAP}-\mathrm{CVP}) \times 80 / \mathrm{CI}$ \\
$\mathrm{DO}_{2}$ & $\mathrm{CI} \times 13.4 \mathrm{Hg} \times \mathrm{SatO}_{2}+0.003 \mathrm{PaO}_{2}$ \\
\hline
\end{tabular}

Legend: Ht, height; Wt, weight; CO, cardiac output; SVRI, systemic vascular resistance índex; MAP, mean arterial pressure; CVP, central venous pressure (assumed as right atrial pressure); $\mathrm{DO}_{2}$, oxygen delivery; $\mathrm{Hg}$, hemoglobin; $\mathrm{SatO}_{2}$, oxygen saturation; $\mathrm{PaO}_{2}$, partial pressure of $\mathrm{O}_{2}$. Note: 13.4 $\mathrm{x}$ Hg is oxygen content, where 13.4 is the amount of oxygen that can be linked to $1 \mathrm{gr} / \mathrm{dl}$ of HG.

Source: Marino, Paul. The ICU Book 2nd Edition. 1998, William and Wilkins, Baltimore USA, Section III, chapter 10, pages 166-177. 
In order to increase the $\mathrm{DO}_{2}$ all these variables can be altered as described earlier ${ }^{[9-12]}$. The first step consists in CO increase, in two sequential steps: first, the intracardiac pressures (central venous pressure [CVP]) or pulmonary capillary wedge pressure $(\mathrm{Pw})$ ) are increased up to supraphysiological values in order to increase the CO to predetermined (also supraphysiological) values, by means of aggressive fluid infusion; then, if not resulted, a continuous infusion of an inotropic agent (dobutamine) is started. The next step consists of red packed cell unit (RPCU) transfusion in order to increase the hemoglobin ( $\mathrm{Hg}$ ) value. The other possibility is to increase the arterial oxygen content or correct the p50 value for hemoglobin dissociation. Roughly, the accepted supraphysiological were: $\mathrm{DO} 2>650 \mathrm{ml} / \mathrm{min} / \mathrm{m}^{2}$; CVP 8-12mmHg; Pw15-18mmHg; CO $>4.51 / \mathrm{m}^{2}[13-15]$.

As it can be easily seen, the results are multiple medical interventions; all aimed towards correcting or achieving supraphysiological values of the monitored variables ${ }^{[16]}$. The patients were easily fluid overloaded, although not all of them were able to achieve the targeted supraphysiological $\mathrm{DO}_{2}$. The iatrogenic burden of these multiple actions is high, and this may be a plausible explanation for the later finding that the use of PACs can lead to higher mortality ${ }^{[17,18]}$, yet not confirmed. It is also clear at this point that all medical actions are aimed to achieve specific physiological (monitored) variables, and not patient variables, defined as therapeutic end-points.

As the observation of higher mortality rates raised concerns 20 years after the introduction of the PAC and invasive monitoring in ICM, the Consensus Conferences held in $1997^{[19,20]}$, found that this practice was sustained on low quality studies, with serious methodological issues. Well-conducted studies carried out afterwards confirmed the basic findings of Connors et al. in $1996^{[6]}$.

A closer analysis of the practice as well as the analysis of the underlying physiological concepts can be quite useful. These physiological concepts were submitted for evaluation and extensively criticized, which was resumed above. For this purpose, we intend to introduce the most relevant information regarding evidence supporting each step of increasing $\mathrm{DO}_{2}$, as explained earlier in the text: increase in CO; accepted Hg levels; excessive fluid therapy and fluid balance.

The CO increase in critical care patients is a questionable end-point ${ }^{[21-23]}$. As a rule, patients are in a hyperdynamic state (particularly patients not in overt heart failure, the vast majority of patients in a medical or surgical ICU), which is mainly characterized by high $\mathrm{CO}$ and the further increase of this particular parameter may be defined by what Heyland stated years ago as, "whipping a tired horse” ${ }^{[24, \text { p.521] }}$. Also the target Hg has changed. Nowadays the best Hg value, within which the best outcome is observed, was established between 7 and $9 \mathrm{~g} / \mathrm{dl}{ }^{[25,26]}$. The excessive oxygen therapy is also under question ${ }^{[27]}$. The excessive fluid therapy must also be criticized in light of recent concepts, ranging from ICM to anesthesiology. The objective of fluid therapy is to increase circulating blood volume. However, in states of high vascular permeability, like sepsis, or even positive pressure ventilation, the fluid administered rapidly goes into the extravascular space, contributing to peripheral edema and not to the increase in intravascular volume. As the organ edema can contribute to end-organ dysfunction, including a delay in renal function recovery, the excessive fluid administered is harmful, and not a part of any therapeutic strategy ${ }^{[28-32]}$.

It is of interest to recall that several mechanisms contribute to fluid dynamics between several body compartments. There are chemical and physical barriers ${ }^{[33]}$. Generally, water moves freely between compartments, sodium reaches equilibrium between the various compartments and larger molecules move with difficulty ${ }^{[33,34]}$.

The pores present in the vascular endothelium are the first barriers encountered. Therefore, due to their size, form or spatial configuration, the molecules may not be able to cross the endothelial barrier. The vascular endothelium may also be continuous, not presenting pores, or discontinuous. The pores may be of various sizes, small or big. Different organs may present different proportions of pores of various sizes, as is found in Table $3^{[34]}$.

The way to assess the increase of intravascular volume after fluid infusion is to observe an increase in CO or in pressure related parameter. However, this is only possible to observe after the volume was administered. The need to distinguish 
patients who might benefit from fluid administration and who do not was established through the dynamic parameters of fluid responsiveness, a set of physiological parameters that present a respiratory variation in the presence of interventricular dependence ${ }^{[35,36]}$. It means that if the left ventricular pressure (and $\mathrm{CO}$ ) is dependent on fluid, during inspiration, a period of reduced blood flow during positive pressure ventilation, the right ventricular pressure will interfere with the left ventricular volume, thus reducing the $\mathrm{CO}$ in this period. Several parameters have been established, such as systolic volume variation, but also echocardiographic parameters: pulsed Doppler variation at the left ventricular outflow tract, and inferior vena cava variation ${ }^{[37-39]}$. Yet the most relevant observed fact is that no static parameter for fluid evaluation (CVP or Pw) is capable of distinguishing the patients who can benefit from fluid infusion ${ }^{[40]}$.

Table 3. Relative size of pores in nanometers and their distribution in the endothelium of different organs

\begin{tabular}{llll}
\hline Tissue & Small Pores & Large pores & Ratio between small and large pores \\
\hline Subcutaneous & 5 & 20 & $1: 3000$ \\
Skeletal Muscle & 6 & 22 & $1: 3600$ \\
Brain & 0,4 & - & - \\
Intestine & 4,6 & 20 & $1: 6400$ \\
Liver & 9,5 & 33 & $1: 50$ \\
Lung & 8 & 20 & $1: 200$ \\
\hline
\end{tabular}

\section{The clinical and therapeutic end-points}

In Paris, 10 years after the Connors et al. study ${ }^{[8]}$ and 30 years after the introduction of PAC into clinical practice, a conference of the European Society of Intensive Care Medicine took place, which established the main clinical end-points for the management of the critically ill ${ }^{[41]}$. They consist mainly of clinical parameters, such as urine output (the hallmark of renal perfusion), consciousness (hallmark of cerebral perfusion), serum lactate levels (hallmark of peripheral and overall organ perfusion), and arterial pressure. These must be considered the end-points of all therapeutic actions, opposing the monitored variables, which must be considered as a way to achieve a goal and not the goal itself.

At this point it is possible to establish the differences between the information derived from diagnostic tools and diagnostic data and eligible clinical end-points. Diagnostic data provides useful or even critical information about a determined status (in this case hemodynamic) of the patient. The variables can be used or manipulated in order to achieve the clinical goal, but it can hardly be considered an end-point itself. It means that in a patient with heart failure (low CO, high peripheral vascular resistance, PVR, and vascular congestion), the therapy is aimed to increase CO to a level that allows the increase in mean arterial pressure and preserve urine output; it is impossible to previously establish a plausible CO, which can vary widely from patient to patient ${ }^{[35]}$. Also, in patients with sepsis, the main hemodynamic component is slow PVR, which can be assessed by any diagnostic tool (for further details, please consult Table 2). The therapeutic action is to infuse a vasopressor, aiming to increase blood pressure and preserve renal flow (as assessed through the urine output) and cerebral flow (as assessed through the level of consciousness). Nonetheless, an integrative approach to the patient must distinguish renal injury or septic encephalopathy ${ }^{[42]}$, both confounding the situation, but relying on clinical assessment ${ }^{[43,44]}$.

A parallel can be established with blood analyses. Through a blood analysis several diagnoses are possible, but the treatment options are not directed to the analyses themselves, but to the specific disease, that manifests itself through analytical or laboratorial changes. Although this issue is beyond the scope of this manuscript, it deserves several constraints in the critical care ${ }^{[45]}$.

These issues are quite relevant in our days. Many new devices are introduced in ICM everyday life, and rarely do they prove any substantial benefit over the ones already existing. The case of continuous monitoring of $\mathrm{CO}$ is a case in point ${ }^{[46,47]}$. Despite the technical characterization and the elegant theoretical models involved, the proof of any advantage is lacking. Why does the critically ill patient need continuous monitoring of CO? In the operative room there exists many 
rapid changes in the hemodynamic profile, attributable mostly to acute bleeding, yet this phenomenon is not observed in the ICU. The hemodynamic profile established upon admission, remains for and is characteristic of the particular disease. An acute change in other monitored variables, such as arterial pressure, should prompt a new hemodynamic assessment. The main feature of the systems working on and based on continuous CO monitoring is their inability to be accurate over time. The manufacturers advise of the necessity for regular calibrations, but after an episode of hemodynamic instability the devices lose their ability to accurately analyze the monitored variable (CO) ${ }^{[48]}$. This is quite evident when using a comparative monitoring system during major surgery. Therefore, the calibrations must be performed often and especially after an episode of hemodynamic instability.

Another parameter that is often used is the central mixed venous saturation $\left(\mathrm{SvO}_{2}\right)$. In this case, there are only two situations in which it is decreased: in deep (great) hypovolemia and in heart failure ${ }^{[49]}$. However, many guidelines use this parameter as an end point value and, most interestingly, using the old models of increasing $\mathrm{DO}_{2}$, namely the Surviving Sepsis Campaign ${ }^{[50,51]}$. This is the case of the sepsis bundles, a mixture of actions where the good actions cannot be discriminated from the unnecessary ones. This is a typical case of a diagnostic tool (mis)used as a therapeutic end-point.

New devices are expensive, both in terms of acquisition costs and consumable materials. The current times of restrictive financial budgets force us to choose the right methods for the right patients, requiring them to be cost effective, as well as supporting good outcomes. Most of the work is performed by basing our practice on current concepts, not on old ones, which can provide good global results.

In our Intensive Care Unit (ICU) we privilege echocardiography as a diagnostic and monitoring tool to assess the critically

ill $^{[52-55]}$. It is a non-invasive method, non-time consuming and does not require the mobilization of a number of health care workers. The information is obtained in real time and, most of the time, before any intravascular device is placed. No sterilized material is necessary. A specific approach for ICM is provided by us in special courses, attended by physicians and other health care personnel. The Fast Assessment Diagnostic Echography (FADE) ${ }^{[66]}$ examinations also explore the pleura and thorax, thus providing additional information (pneumothorax, pneumonia, lung edema, pleural effusion with its quantity and characteristics), and preventing many patients from undergoing other examinations (computer tomography) to provide differential diagnosis of several situations. The costs are related to equipment acquisition and training, which is more intense than the simple placement of an intravascular device. This is a modern approach to the critically ill which provides sufficient diagnostic information, permitting correct patient management, based on clinical end-points.

It is noteworthy that at this time there is no particular diagnostic device that is proved to be superior in patient management or outcome. As a matter of fact, PAC is the only diagnostic tool that was extensively studied with regards to its usefulness and patient safety ${ }^{[14,57,58]}$. To our knowledge in the available literature no other device was subjected to patient safety screening; the information is limited to technical characteristics and eventual indications for use ${ }^{\text {[59] }}$. Taking this into consideration, the choice relies mainly on the experience of the health practitioner and specific work culture of the ICU.

\section{Bioethical issues in monitoring devices}

Monitoring vital functions is a common feature in several medical specialties. The practice of ICM and major surgery or anaesthesiology uses several monitoring devices and parameters in order to detect vital function parameters, permitting clinicians to, consequently, correct them.

We propose to analyze the meaning and consequences of monitoring procedures, focusing on the real and proved impact on actual patient management and its contribution towards the total budget burden of health care.

The word monitore is a Latin word that means advising ${ }^{[60]}$. It became popular in Medicine in the 1960s due to several facts: 
- The defibrillator was described and proved to be efficacious in stopping severe life-threatening arrhythmias;

- These severe life-threatening arrhythmias proved to be the major cause of death among patients with acute myocardial infarction (AMI);

- The advent of major surgery, namely cardiac surgery.

The first two events are closely linked to the need felt towards a continuous registration of the patient's cardiac electrical activity, in order to stop the life-threatening event (malignant arrhythmia). Thus, the first monitoring devices emerge as surveillance devices, aimed to provide continuous registration of a physiological parameter. This concept did not undergo significant change over time ${ }^{[61-63]}$.

The ICUs share a basic panoptical architecture, designed centuries ago by Jeremy Bentham for the surveillance of a great amount of prisoners by a scarce number of guards. They simulate the basic architecture of prisons and psychiatric hospitals ${ }^{[64]}$. The advent of Intensive Care Units (ICU) brought more artificial life sustaining methods such as, artificial ventilation, hemodynamic data obtained at the bedside. Consequently, the amount of monitored data, or physiological variables, increased.

The industry linked to the growing number of devices, including the monitor itself and the methodology to obtain the monitored variables also grew significantly. Consequently, new data and scientific knowledge were added. The best example is the PAC itself, which permitted us to better understand the physiological principles of each shock state ${ }^{[65]}$. The consequences were dramatic. The appearance of our hospitals changed, making the ICU a highly technological department. Other consequences can also be noted:

- The contact between the attending physician and the patient changed. The patient is viewed and analysed through a monitoring screen, the physical contact is often minimal;

- $\quad$ The clinical practice and widely accepted guidelines are markedly influenced by new devices and instruments;

- The number of medical interventions rose significantly. The more physiological parameters monitored the more medical acts occurred;

- $\quad$ The necessity for more training of both medical and nursing staff increase the costs associated with new technology ${ }^{[66]}$;

- The costs related to this specialized care rose significantly. All new drugs or devices are much more expensive than the previous ones not only due to ascending economic values worldwide but also due to the greater training time associated to new device acquisition.

Ethically speaking, the assessment of all these changes should be carefully carried out. All four principles of Medical Bioethics, as enounced by Beauchamp and Childress are present: beneficence, autonomy, non-malfeasance, and justice ${ }^{[69]}$.

The first principle is beneficence, which is defined by the obligation to do good to others, obliges us to provide the best evidence-based care to every patient, improving the standards of care and life. This state of the art care should be founded on the best evidence based procedures.

One assumption seems mandatory: this technological invasion changed dramatically our standard of life, improving the quantity and quality of life. If this assumption is true then the effort of the heath care provider is worthwhile.

It is possible to criticize this assumption, at least in all aspects of technological development. The increase in life standards in Western societies are a part of multiple advances. In Medicine, a better understanding of the pathophysiology of the diseases, pharmacological advances (namely antibiotics), and several other aspects has to be mentioned to establish the 
basis for better life standards and modification of the natural history of the diseases. As was exposed previously, the presence of excessive monitoring devices can actually harm the patient ${ }^{[66]}$, as demonstrated in the past by the abovementioned example of the PAC.

Also, the issues of accepted ethical principles applied to clinical investigation must be also applied to new monitoring devices.

If the patient is in critical condition, the informed consent is many times waived, as well as, the consent of the relatives because most situations require immediate procedures, and the conscience level of the patient may be not adequate ${ }^{[67,68]}$. Also, the time for a thorough explanation to the relatives may not be enough, thus their decision is more complex and second opinions are often not available. More research in this area would be recommended. Nonetheless, all medical practice must be sustained on scientific evidence, not on good ideas, which can be assumed as having good intrinsic logic, but lacking any accepted evidence. This type of reflection will help health care professionals to avoid what was once called the iatroepidemics ${ }^{[70]}$, meaning that the performance of diagnostic procedures, not supported by an adequate level of evidence or in other words, unnecessary, can ultimately put the patient’s life at an unnecessary risk.

\section{Conclusion}

In any healthcare setting a careful approach to the patient is needed, namely in ICM one must consider their clinical condition and choose adequate diagnostic tools and devices. Not all variables and devices currently on the market are suitable for each patient, nor proved useful in ICM. Besides, not all patients are equal, and each one must be approached differently according to established clinical end-points and not simply to normalized monitored values; assisting the clinicians and multi-disciplinary team in approaching the patient more holistically. A closer approach towards the patient's individual needs is required in ICM. All models of diagnostic tools and monitoring devices must be carefully chosen and submitted to criticism not only due to patient benefits and ethical standpoints but also, due to current financial constraints. The knowledge of the physiological principles involved, as well as the basis of the different concepts that rely on the starting points of the different approaches, should strengthen our practice in the ICU.

The monitoring for each patient should be performed according to individual goals for the patient and their disease. Each monitoring tool must be regarded as such, the diagnosis must be performed correctly and the therapeutic approach must be directed to individual clinical end-points; the normalization of monitored variables must not be encouraged, excessive therapeutic interventions must also be avoided, as they are likely to end in iatrogenic insult.

\section{References}

[1] Wentworth Area Health Service. Pulsion Pico. Available from: http://intensivecare.hsnet.nsw.gov.au/five/doc/pulse_contour_cardiac_output_PICCO_HM_nepean.pdf (15 October 2013, date last accessed).

[2] Zhongheng Zhang, Xiao Xu, Min Yao, Huilan Chen, Hongying Ni and Haozhe Fan. Use of the PiCCO system in critically ill patients with septic shock and acute respiratory distress syndrome: a study protocol for a randomized controlled trial. Trials. 2013; 14: 32. PMid:23374652 http://dx.doi.org/10.1186/1745-6215-14-32

[3] Forssman W. Die Sondierung der rechten hertzens. Berlin Klin Wochenschr. 1929; 8: 2027-2029.

[4] Branthwaite MA, Bradley RD. Measurement of cardiac output by thermal dilution in man. J Appl Physiol. 1948; 24 : 434-438.

[5] Lategola M, Rahn H. A self-guided catheter for cardiac and pulmonary arterial catheterization and occlusion. Proc Soc Exp Biol Med. 1953; 84: 667-668. http://dx.doi.org/10.3181/00379727-84-20745

[6] Bradley RD. Diagnostic right-heart catheterization with miniature catheters in severely ill patients. Lancet. 1964 ; ii: $941-942$. http://dx.doi.org/10.1016/S0140-6736(64)90869-4 
[7] Swan HCJ, Ganz W, Forrester, Marcus H, Diamond G, and Chonette D. Catheterization of the right heart in man with use of a flow-directed balloon-tiped catheter. N Eng J Med. 1970; 283: 447-451. PMid:5434111 http://dx.doi.org/10.1056/NEJM197008272830902

[8] Connors AF, Speroff T, Dawson N, Thomas C, Harrell F, Wagner D, et al. The effectiveness of right heart catheterization in the initial care of critically ill patients. JAMA. 1996; 276: 889-897. PMid:8782638 http://dx.doi.org/10.1001/jama.1996.03540110043030

[9] Shoemaker WC, Montgomery ES, Kaplan E, et al. Physiologic patterns in surviving and non-survivng shock patients: use of sequential cardiorespiratory parameters in defining criteria for therapeutic goals and early warning of death. Arch Surg. 1973; 106: 630-636. PMid:4701410 http://dx.doi.org/10.1001/archsurg.1973.01350170004003

[10] Shoemaker WC, Appel PL, Bland R, et al. Use of physiologic monitoring to predict outcome and to assist in clinical decisions in critically ill post operative patients. Am J Surg. 1983; 1: 43-50. http://dx.doi.org/10.1016/0002-9610(83)90257-X

[11] Shoemaker WC, Appel PL, Kram HB, Waxman K, Lee T-S. Prospective trial of supranormal values of survivors as therapeutic goals in high-risk surgical patients. Chest. 1998; 94: 1176-1186. http://dx.doi.org/10.1378/chest.94.6.1176

[12] Tuchschmidt J, Fried J, Astiz M, Rackow E. Elevation of cardiac output and oxygen delivery improves outcome in septic shock. Chest. 1992; 102: 216-220. PMid:1623756 http://dx.doi.org/10.1378/chest.102.1.216

[13] Hocham JS, Boland J, Sleeper LA et al. Curent spectrum of cardiogenic shock and effect of early revascularization on mortality. Circulation. 1995; 91: 873-881. http://dx.doi.org/10.1161/01.CIR.91.3.873

[14] Ivanova R, Allen J, Calvin JE. The incidence of major morbidity in critically ill patients managed with pulmonary artery catheters: a meta-analysis. Crit Care Med. 2000; 28: 615-619. http://dx.doi.org/10.1097/00003246-200003000-00002

[15] Afessa B, Spencer S, Khan W et al. Association of pulmonary artery catheter use and in-hospital mortality. Crit Care Med. 2001; 29: 1145-1148. PMid:11395590 http://dx.doi.org/10.1097/00003246-200106000-00010

[16] Menitz PG, Reiter A, Jordan B, Lang T. More interventions do not necessarily improve outcome in critically ill patients. Intensive Care Med. 2004; 30: 1586-1593.

[17] Guyatt G. A randomized control trial of right-heart catheterization in critically ill patients. The Ontario Intensive Care Study Group. J Intensive Care Med. 1991; 6: 91-95. PMid:10147952

[18] Bernard G, Sopko G, Cerra F et al. Pulmonary artery catheterization and clinical outcomes. JAMA. 2000 ; $283: 2568-2572$. PMid:10815121 http://dx.doi.org/10.1001/jama.283.19.2568

[19] Bernard GR, Sopko G, Cerra F, Demling R, Edmunds H, Kaplan S, et al. Pulmonary artery catheterization and clinical outcomes: National Heart, Lung, and Blood Institute and Food and Drug Administration Workshop Report. Consensus Statement. JAMA. 2000 May 17; 283(19): 2568-72. PMid:10815121 http://dx.doi.org/10.1001/jama.283.19.2568

[20] Rackow EC. Pulmonary Artery Catheter Consensus Conference. Crit Care Med. 1997 Jun; 25(6): 901. PMid:9201037 http://dx.doi.org/10.1097/00003246-199706000-00001

[21] Hayes MA, Timmins AC, Yau EH, Polazzo M, Watson D, Hinds CJ. Oxygen transport patterns in patients with sepsis syndrome or septic shock. Crit Care Med. 1997; 25: 926-936. PMid:9201043 http://dx.doi.org/10.1097/00003246-199706000-00007

[22] Gattinoni L, Brazzi L, Pelosi P, Latini R, Tognoni G, Pesenti A, et al. A trial of goal-oriented hemodynamic therapy in critically ill patients. N Eng J Med. 1995; 333: 1025-1032. PMid:7675044 http://dx.doi.org/10.1056/NEJM199510193331601

[23] Durham R, Neunaber K, Mazuski JE, Shapiro M, Baue A. The use of oxygen consumption and delivery as end-points for resuscitation in critically ill patients. J Trauma. 1996; 41: 32-40. PMid:8676421 http://dx.doi.org/10.1097/00005373-199607000-00007

[24] Heyland DK, Cook DJ, King D, Kernerman P, Brun-Buisson C. Maximizing oxygen delivery in critically ill patients: a methodologic appraisal of the evidence. Crit Care Med. 1996 Mar; 24(3): 517-24. PMid:8625644 http://dx.doi.org/10.1097/00003246-199603000-00025

[25] Hébert PC, Wells G, Marshall J, Martin C, Tweeddale M, Pagliarello G, et al. Transfusion requirements in critical care. A pilot study. Canadian Critical Care Trials Group. JAMA. 1995 May 10; 273(18): 1439-44. PMid:7723158 http://dx.doi.org/10.1001/jama.1995.03520420055038

[26] Hébert PC, Wells G, Blajchman MA, Marshall J, Martin C, Pagliarello G, et al. A multicenter, randomized, controlled clinical trial of transfusion requirements in critical care. Transfusion Requirements in Critical Care Investigators, Canadian Critical Care Trials Group. N Engl J Med. Feb 11 1999; 340(6): 409-17. PMid:9971864 http://dx.doi.org/10.1056/NEJM199902113400601

[27] Bryan CL, Jenkinson SG. Oxygen toxicity. Clin Chest Med. 1988 Mar; 9(1): 141-52. PMid:3280227

[28] Payen D, de Pont A, Sakr Y, et al. A positive fluid balance is associated with a worse outcome in patients with acute renal failure. Crit Care. 2008; 12 (R74). PMid:18533029 
[29] Alsous F, Khamiees M, DeGirolamo A, Amoateng-Adjepong Y, Manthous CA. Negative fluid balance predicts survival in patients with septic shock: a retrospective pilot study. Chest. 2000; 117: 1749-1754. PMid:10858412 http://dx.doi.org/10.1378/chest.117.6.1749

[30] Varon J, Fromm RE. Fluid balance in sepsis. Are we ready for a negative balance? Chest. 2000; 117: 1535-1536. PMid:10858378 http://dx.doi.org/10.1378/chest.117.6.1535

[31] Wenkui Y, Ning L, Jianfeng G, Weiqin L, Shaoqiu T, Zhihui T, et al. Restricted peri-operative fluid administration adjusted by serum lactate level improved outcome after major elective surgery for gastrointestinal malignancy. Surgery. 2010 Apr; 147(4): 542-52. PMid:20004445 http://dx.doi.org/10.1016/j.surg.2009.10.036

[32] Sadaka F, Juarez M, Naydenov S, O'Brien J. Fluid Resuscitation in Septic Shock: The Effect of Increasing Fluid Balance on Mortality.J Intensive Care Med. 2013. http://dx.doi.org/10.1177/0885066613478899

[33] Zeuthen T, MacAulay N. Passive water transport in biological pores. Int Rev Cytol. 2002; 215: 203-30. http://dx.doi.org/10.1016/S0074-7696(02)15010-8

[34] Sarin, H. Physiological upper limits of pore size of different blood capillary types and another perspective on the dual pore theory of microvascular permeability. Journal of Angiogenesis Research. 2010; 2: 14. PMid:20701757 http://dx.doi.org/10.1186/2040-2384-2-14

[35] Teboul JL. Dynamic concepts of volume responsiveness. Intensive Care. 2003; 10: 49-50.

[36] Tavernier B, Makhotine O, Lebuffe G, Dupont J, Scherpreel P. Systolic pressure variation as a guide to fluid therapy in patients with sepsis-induced hypotension. Anesthesiology. 1998; 89: 1313-1321. PMid:9856704 http://dx.doi.org/10.1097/00000542-199812000-00007

[37] Marx G, Cope T, McCrossan L, Swaraj S, Cowan C, Mostafa SM, et al. Assessing fluid responsiveness by stroke volume variation in mechanically ventilated patients with severe sepsis. Eur J Anaesthesiol. 2004; 21: 132-138. PMid:14977345 http://dx.doi.org/10.1017/S0265021504002091

[38] Barbier C, Loubieres Y, Schmit C, Hayon C, Ricôme J-L, Jardin F, et al. Respiratory changes in inferior vena cava diameter are helpful in predicting fluid responsiveness in ventilated patients. Intensive Care Med March 18, 2004. 03-18-2004.

[39] Feissel M, Michard F, Mangin I, Ruyer O, Faller J-P, Teboul JL. Respiratory changes in aortic blood flow velocity as an indicator of fluid responsiveness in ventilated patients with septic shock. Chest. 2001; 119: 867-873. PMid:11243970 http://dx.doi.org/10.1378/chest.119.3.867

[40] Marik PE, Cavallazzi R. Does the central venous pressure predict fluid responsiveness? An updated meta-analysis and a plea for some common sense. Crit Care Med. 2013 Jul; 41(7): 1774-81. PMid:23774337 http://dx.doi.org/10.1097/CCM.0b013e31828a25fd

[41] Antonelli M, Levy M, Andrews PJD, Chastre J, Hudson LD, Manthous C, et al. Hemodynamic monitoring in shock and implications for management. In International Consensus Conference, Paris, France, 27-28 April 2006. Intensive Care Med. 2006; 33: 575-590. PMid:17285286 http://dx.doi.org/10.1007/s00134-007-0531-4

[42] Adam N, Kandelman S, Mantz J, Chrétien F, Sharshar T. Sepsis-induced brain dysfunction. Expert Rev Anti Infect Ther. 2013 Feb; 11(2): 211-21. PMid:23409826 http://dx.doi.org/10.1586/eri.12.159

[43] Gofton TE, Young GB. Sepsis-associated encephalopathy. Nat Rev Neurol. 2012 Oct; 8(10): 557-66. PMid:22986430 http://dx.doi.org/10.1038/nrneurol.2012.183

[44] Sharshar T, Polito A, Checinski A, Stevens RD. Septic-associated encephalopathy--everything starts at a microlevel. Crit Care. 2010; 14(5): 199. PMid:21067627 http://dx.doi.org/10.1186/cc9254

[45] Ezzie ME, Aberegg SK, O'Brien JM Jr. Laboratory testing in the intensive care unit. Crit Care Clin. 2007 Jul; $23(3)$ : $435-65$. PMid:17900480 http://dx.doi.org/10.1016/j.ccc.2007.07.005

[46] Linton RA, Band DM, Haire KM. A new method of measuring cardiac output in man using lithium dilution. Br J Anaesth. 1993 Aug; 71(2): 262-6. PMid:8123404 http://dx.doi.org/10.1093/bja/71.2.262

[47] Litton E, Morgan M. The PiCCO monitor: a review. Anaesth Intensive Care. 2012 May; 40(3): 393-409. PMid:22577904

[48] Pissarra F, Oliveira A, Marcelino P. Transoesophageal echocardiography for monitoring liver surgery: data from a pilot study. Cardiol Res Pract. 2012; 2012: 723418.

[49] Teboul JL, Hamzaoui O, Monnet $\mathrm{X}$. $\mathrm{SvO}_{2}$ to monitor resuscitation of septic patients: let's just understand the basic physiology. Crit Care. 2011; 15(6): 1005. PMid:22078239 http://dx.doi.org/10.1186/cc10491

[50] Dellinger RP, Levy MM, Rhodes A, Annane D, Gerlach H, Opal SM, et al. Surviving sepsis campaign: international guidelines for management of severe sepsis and septic shock: 2012.Surviving Sepsis Campaign Guidelines Committee including the Pediatric Subgroup. Crit Care Med. 2013 Feb; 41(2): 580-637. PMid:23353941 http://dx.doi.org/10.1097/CCM.0b013e31827e83af 
[51] Bouferrache K, Amiel JB, Chimot L, Caille V, Charron C, Vignon P, et al. Initial resuscitation guided by the Surviving Sepsis Campaign recommendations and early echocardiographic assessment of hemodynamics in intensive care unit septic patients: a pilot study. Crit Care Med. 2012 Oct; 40(10): 2821-7. PMid:22878678 http://dx.doi.org/10.1097/CCM.0b013e31825bc565

[52] Dellinger RP, Levy MM, Rhodes A, Annane D, Gerlach H, Opal SM, et al. Surviving sepsis: going beyond the guidelines. Ann Intensive Care. 2011 Jun 7; 1(1): 17. PMid:21906348 http://dx.doi.org/10.1186/2110-5820-1-17

[53] Cholley B, Vieillard-Baron A, Mebazaa A. Echocardiography in the ICU: time for widspread use. Intensive Care Med. 2005; 32: 9-10. PMid:16292627 http://dx.doi.org/10.1007/s00134-005-2833-8

[54] Beaulieu Y, Marik P. Bedside ultrasonography in the ICU. Part 1. Chest. 2005; 128: 881-895. PMid:16100182 http://dx.doi.org/10.1378/chest.128.2.881

[55] A. Figueiredo, M Oliveira, S. Marum, P. Marcelino. Book Chapter. Critical Care Ultrasound. Principles and Practice. In Horizons in World Cardiovascular Research. Volume 4, 2011. New York. Edited by Eleanor H. Bennington: Nova Science Publishers.

[56] Marum S, Price S. The use of echocardiography in the critically ill; the role of FADE (Fast Assessment Diagnostic Echocardiography) training. Curr Cardiol Rev. 2011 Aug; 7(3): 197-200. PMid:22758617 http://dx.doi.org/10.2174/157340311798220449

[57] Afessa B, Spencer S, Khan W et al. Association of pulmonary artery catheter use and in-hospital mortality. Crit Care Med. 2001; 29: 1145-1148. PMid:11395590 http://dx.doi.org/10.1097/00003246-200106000-00010

[58] Chittock DR, Dhingra VK, Ronco JJ et al. Severity of illness and risk of death associated with pulmonary artery catheter use. Crit Care Med. 2004; 32: 911-915. PMid:15071376 http://dx.doi.org/10.1097/01.CCM.0000119423.38610.65

[59] Cardiac output monitoring devices: an analytic review. Porhomayon J, El-Solh A, Papadakos P, Nader ND. Intern Emerg Med. 2012 Apr; 7(2): 163-71. PMid:22147648 http://dx.doi.org/10.1007/s11739-011-0738-9

[60] Advising; monitore Dictionary Reference. http://dictionary.reference.com/browse/monitor?s=t (15 July 2013, date last accessed).

[61] Zoll PM, Linenthal AJ, Norman LR, Paul MH, Gibson W. Treatment of unexpected cardiac arrest by external electric stimulation of the heart. N Engl J Med. 1956 Mar 22; 254(12): 541-6. PMid:13297150 http://dx.doi.org/10.1056/NEJM195603222541201

[62] Jude JR, Kouwenhoven WB, Knickerbocker GG. Cardiac resuscitation without thoracotomy. Md State Med J. 1960 Oct; 9: 712-3. PMid:13790920

[63] Reynell PC. Coronary care unit in a general medical ward. Br Med J. 1969 May 24; 2(5655): 502-3. PMid:5771584 http://dx.doi.org/10.1136/bmj.2.5655.502

[64] Strub H.The theory of panoptical control: Bentham's panopticon and Orwell's Nineteen eighty-four. J Hist Behav Sci. 1989 Jan; 25(1): 40-59. http://dx.doi.org/10.1002/1520-6696(198901)25:1<40::AID-JHBS2300250104>3.0.CO;2-W

[65] Marino, Paul. The ICU Book., 2nd Edition, 1998 William and Wilkins. Chapters 14 and 16.

[66] Titler MG. Technology dependency and iatrogenic injuries. Nurs Clin North Am. 1993 Jun; 28(2): 459-73. AACN Clin Issues. 2002 May; 13(2): 204-20.

[67] Kurt M. Hartman, JD Bryan A. Liang, MD, PhD, JD. Exceptions to Informed Consent in Emergency Medicine. Hospital Physician March. 1999; 53-59.

[68] O'Neill. Some limits of informed consent. Symposium on consent and confidentiality. Journal of Medical Ethics J Med Ethics. 2003; 29: 4-7.

[69] Beauchamp TL, Childress JF. Principles of Medical Bioethics. Oxford University Press, 2001.

[70] Robin ED. Iatroepidemics: a probe to examine systematic preventable errors in (chest) medicine. Am Rev Respir Dis. 1987 May; 135(5): 1152-6. PMid:3579013 